\title{
STUDENTS WITH LANGUAGE LEARNING DISABILITIES AND DIFFICULTIES IN A FOREIGN LANGUAGECLASSROOM
}

\author{
Maja IVANČEVIĆ OTANJAC \\ University of Belgrade \\ Faculty of Special Education and Rehabilitation
}

The aim of this paper is to present a brief review of the factors significant for foreign language learning, with special emphasis on students with language learning disabilities and difficulties. The paper overviews the available literature on how native language skills and foreign language aptitude influence the success in foreign language acquisition. Also, it points out the importance of teachers' role and appropriate teaching modifications and methods suitable for students who have difficulties in foreign language learning.

Key words: language learning difficulties, native language skills, foreign language aptitude, instructional modifications

\section{INTRODUCTION}

With English becoming a global language, there is an increasing number of foreign language learners who are learning it for different reasons. Nowadays, there is almost no school curriculum in which English language is not one of the core subjects. It would not be wrong to say that probably most students in the world study English because it is on their school

1 E-mail: majaotanjac@fasper.bg.ac.rs 
curriculum (Harmer, 2001). In Serbia, English as a foreign language is studied from the first grade of elementary school and is an integral part of the curriculum in both elementary and secondary schools. Also, in most schools, students get a second foreign language (usually French, German, Russian or Italian) in the $3^{\text {rd }}$ or $5^{\text {th }}$ grade of elementary school, and study it throughout secondary school along with English. Thus, school-age learners usually do not have a choice about whether to learn foreign languages or not. Because of this, foreign language teachers have a challenging task to motivate their students and interest them in their school subject. It is their responsibility to make sure that the materials and tasks they use in their classroom are organized and implemented in a way that they meet individual learners' needs. This becomes even more challenging in an inclusive classroom where the educational needs of students with disabilities differ from those of typically developing students, and where additional modifications and accommodations may be necessary.

This paper overviews some key factors for successful implementation of foreign language teaching with special emphasis on learners with language learning disabilities and difficulties. The paper emphasizes the importance of different factors relevant to foreign language learning of students with mentioned difficulties, such as students' native language skills, aptitude in foreign language learning, teachers' role in educating these students, and the choice of appropriate teaching methods and necessary instructional modifications.

\section{Students with Language Learning Disabilities and Difficulties}

Inclusion is defined "as a process of addressing and responding to the diversity of needs of all children, youth and adults through increasing participation in learning, cultures and communities, and reducing and eliminating exclusion" (UNESCO, 2009:8). In an inclusive environment, all students 
with special needs, regardless of the type and severity of their disability or difficulty, attend regular schools in their neighborhood, and they are the responsibility of general education teachers (Hallahan, Kauffman \& Pullen, 2009). Furthermore, it is a general teacher's responsibility to address weakness areas of students with disabilities and difficulties by making instructional and content modifications, and in some cases, to take part in identification of these students in class. This especially refers to the identification of students with language-based learning disabilities (LBLD). Newhall (2012) defines language-based learning disabilities as "a spectrum of difficulties related to the understanding and use of spoken and written language" (Newhall, 2012). Some students with LBLD are identified at an early age. However, many students with this disorder go through early elementary school with few problems. It is only when the educational demands and expectations rise that their language-based learning disabilities become identified (Newhall, 2012). Schwarz (1997) suggests that sometimes even those students who were not previously diagnosed with a learning disability (LD) turned out to be learning disabled in a foreign language class. If a child has language delays in the native language, difficulties in native language literacy skills, specific language weaknesses in both native language and English (e.g. phonological), and if there is a family history of reading disabilities, and no progress after appropriate intervention, the possibility of a learning disability is present (Spear-Swerling, 2006). Most academic problems of these children result from difficulties in language and literacy skills, including listening, speaking, reading, writing and spelling, as well as difficulties in attention, memory, and executive functions.

It is important to make a distinction between language disabilities and language difficulties. In their review article on Learning Difficulties and Foreign Language Learning, Ganschow and Sparks (2001) use the term learning disabilities to refer to students who were diagnosed with this disability, while they use the term at-risk to describe individuals who 
expressed difficulties in foreign language courses at school. They found that many students without learning disabilities experienced foreign language learning difficulties. With regard to students of English as a foreign language, Yates and Ortiz (1998) suggest that "educators have difficulty distinguishing students who truly have learning disabilities from students who are failing for other reasons" (Yates \& Ortiz, 1998 in Ortiz 2001). Di Fino and Lombardino (2004) identified three global problem areas for all foreign language learners which may cause foreign language learning difficulties. These problem areas include poor memorization skills, a high level of anxiety which paralyses a student in class, and lexical-grammar confusion which causes students to fail in learning a grammar concept due to their inability to understand grammar terms. However, even if a student is not diagnosed with LD, but only exhibits difficulties in a foreign language class, the same educational intervention should be applied. If not timely addressed with appropriate instructional modifications, these difficulties may over time become more serious and create a wider gap between the achievements of students with foreign language learning difficulties and their peers (Ortiz, 2001).

In their article on language learning disabilities in university students, DiFino and Lombardino (2004) provide a checklist of warning signs which may help in identifying at-risk students. General warning signs may include: poor performance on quizzes and tests despite regular attendance, homework and assignments; students often feel confused during a lesson and are either too silent or ask questions too frequently; students feel frustrated and behave inappropriately (e.g. aggressively towards the teacher) due to their inability to cope with course materials; students need more time to complete tasks and work at a slower pace than their classmates; students are easily distracted and find it difficult to follow teacher's directions (DiFino \& Lombardino, 2004). 


\section{Native Language Skills in Learners with Language Learning Disabilities and Difficulties}

Sparks and Ganschow introduced the Linguistic Coding Differences Hypothesis (LCDH) according to which native oral and written language skills, as well as foreign language aptitude, are key factors in foreign language acquisition (Sparks et al., 1989; Sparks \& Ganschow, 1991 in Ganschow, Sparks \& Javorsky, 1998). Their research determined that difficulties in foreign language acquisition largely depend on problems with one language skill, most often phonological/orthographic aspects of language which then have a negative influence on both native and foreign language systems. As pointed out in their review article on Learning Difficulties and Foreign Language Learning (Ganschow \& Sparks, 2001), learning disabled and atrisk students "showed poorer performance than good foreign language learners on native language measures" (Ganschow \& Sparks, 2001:93). The relation between native and foreign language skills was also supported by more recent studies. In their research on Writing Abilities in First and Second Language Learners With and Without Reading Disabilities, Ndlovu and Geva (2008) obtained results which indicated that there were no significant differences between the achievements of English as a second language and first language learners. They concluded that a more significant factor of failure in writing abilities was the presence of reading disabilities than the language status. Furthermore, Geva and Massey-Garrison (2013) compared language skills of English as a second language learners and English as a first language learners who had poor decoding skills, poor comprehension skills, or were normal readers. They concluded that students with problems in decoding and comprehension had difficulties with various language aspects, again regardless of language status, i.e. whether English was their first or second language. 
Specijalna edukacija i rehabilitacija (Beograd), Vol. 15, br. 4. 461-474, 2016.

Also, Ganschow and Schneider (2006) point out that further problems for students with language learning difficulties may be caused by numerous differences between a student's native language and the foreign language he/she is studying. These differences may include sound-symbol correspondence, morphological complexity, or syntactic rules. For example, Serbian is a language with very simple soundsymbol correspondence, in which a single letter represents a single sound. Thus, Serbian students may have significant problems with English phonological/orthographic rules where this correspondence is very complex, i.e. several different letters can represent the same sound, and different sounds can be represented by one same letter.

As Ganschow et al. (1998) conclude, all poor foreign language learners, with or without LD diagnosis, typically have problems with native language skills (primarily phonological/ orthographic aspects of language) and exhibit weaker foreign language aptitude, which then has a negative influence on foreign language acquisition.

\section{Foreign Language Aptitude in Learners with Language Learning Disabilities and Difficulties}

Foreign language aptitude (FLA) is a significant factor in defining language learning disabilities and difficulties. This is supported by the fact that such disabilities and/or difficulties may be described as low aptitude for learning foreign languages.

Aptitude was first defined by the American psychologist and prominent scholar in the field of linguistics and foreign language learning John B. Carroll as "the notion that in approaching a particular learning task or program, the individual may be thought of as possessing some current state of capability of learning that task" (Carroll, 1981:84, cited in Tonkyn, 1998: H8). In terms of language aptitude, Ellis (1994) 
suggests that this capability involves a special propensity for learning a foreign language, which implies that some learners are predisposed to be more successful in acquiring a foreign language than others. In discussing language aptitude, Skehan (1991) implies that it is a talent which is not related to intelligence or previous learning experience, and which is relatively stable and differs among students.

Two main instruments for measuring aptitude are the Modern Languages Aptitude Test (MLAT) developed by Carroll and Sapon in 1959, and the Pimsleur Language Aptitude Battery (PLAB), similar to MLAT in many ways and designed mainly for secondary age students by Paul Pimsleur in 1966. The MLAT is the most commonly used instrument for measuring language aptitude which consists of five sections: 1-Number Learning, 2-Phonetic Script, 3-Spelling Clues, 4-Words in Sentences, and 5-Paired Associates. The author of the test identified four factors of foreign language learning aptitude: 1) phonemic coding ability (sections 2 and 3 of the MLAT) related to sound-system relationships; 2) grammatical sensitivity (section 4 of the MLAT) related to the ability to recognize grammatical functions of words within a sentence; 3) inductive language learning ability (section 4 of the MLAT) related to the ability to deduce general linguistic principles from language samples (involving either semantic or syntactic structure); and 4) rote learning ability (sections 1 and 5 of the MLAT) related to vocabulary learning by remembering associations with paired translations (Carroll, 1962, 1981, 1990, cited in Sparks, Patton, Ganschow, Humbach \& Javorsky, 2006; Tonkyn, 1998). Despite the fact that it was developed in 1959 , and that its norms are fairly outdated, the MLAT is still a popular aptitude test frequently used in research studies (Sparks et al., 2006). In fact, Ellis (1994) suggests that there have been "almost no attempts to develop alternative language aptitude tests" (Ellis, 1994: 499).

In their research on Aptitude, Individual Differences, and Instructional Design, Sawyer and Ranta (2001) report the results of Carroll's studies (Carroll, 1981 in Sawyer \& Ranta, 
2001) on the relation between the success in learning a foreign language and language aptitude, measured by means of the MLAT. Carroll's results showed a strong correlation between language learning achievement and language aptitude. However, Sawyer and Ranta conclude that further research is needed in this field, especially in the measurement of language aptitude, learner profiles, individual differences, the influence of aptitude differences on particular language learning tasks, and the influence of different tasks on various types of learners.

More recently, Sparks et al. (2009) conducted a study on Long-Term Relationships Among Early First Language Skills, Second Language Aptitude, Second Language Affect, and Later Second Language Proficiency. Their results indicate that even though there were strong correlations between native language skills and foreign language proficiency, the MLAT was the best predictor of second language proficiency. Furthermore, in their paper on Learning Difficulties and Foreign Language Learning, Ganschaw and Sparks (2001) present a review of studies conducted on students with learning difficulties. They determined that apart from the previously mentioned native language skills, another best predictor of foreign language proficiency was the MLAT. They also suggest that students with learning disabilities and at-risk students achieved similar results on tests which measure native language skills and foreign language aptitude. Similar findings were reported by Gajar back in 1987 who investigated predictors of success in foreign language learning and diagnostic variables in foreign language learning disabilities in a sample of learning disabled university students. Again, the results in the MLAT proved to be significant predictive and diagnostic variables (Gajar, 1987). 


\section{Teachers' Role and Appropriate Instructional Methods}

Teachers have a key role in implementing the curriculum. Very frequently, particularly in foreign language schools in Serbia, the curriculum is organized around textbooks prescribed by the school itself. It is then teachers' task to make the best of the materials they have to use in class. As Richards (2001) points out, even if teaching materials are of relatively poor quality, exceptional teachers can usually compensate for that. On the other hand, very well-designed teaching materials will not guarantee success in foreign language learning if the teachers lack qualifications, motivation, training, experience, and language proficiency. Foreign language teachers who work in an inclusive classroom may have additional problems due to insufficient (if any) training and qualifications in working with exceptional children. Apart from all the above mentioned qualities of good language teachers, these teachers also need to be open-minded towards working in inclusive classrooms, and willing to adapt teaching materials and methods to meet the needs of students with disabilities or difficulties.

Teachers who teach students with foreign language learning difficulties are faced with numerous challenges. Ganschow and Schneider (2006) state that training and education for foreign language teachers usually prepares them for the "ideal learner" who is expected to master language skills (pronunciation, reading, writing, speaking and listening) through exposure and practice. They point out the need for additional training in meeting the needs of students with special needs. Foreign language teachers should learn to determine the most beneficial accommodations for their students, and to identify students at risk of developing a foreign language learning disability as early as possible (Ganschow \& Schneider 2006).

Although scarce, there are studies which show that with appropriate instructional modifications, students with language 
learning difficulties can succeed in studying a foreign language. For example, Sparks et al. (Sparks et al., 1998 in Ganschow \& Sparks, 2001) conducted a study with the aim to determine if multisensory structured language (MSL) instruction was superior to other approaches in teaching at-risk learners. Their results indicate that MSL instruction positively influences foreign language learning. Other authors also point out the importance of structured, multisensory instruction for students with language learning difficulties (Schwarz, 1997; DiFino \& Lombardino, 2004; Ganschow \& Schneider, 2006; Newhall, 2012). Ganschow and Schneider, (2006) offer suggestions for teachers working in an inclusive foreign language classroom, based on eight MLS principles: 1 - Multisensory (teaching using visual, auditory, tactile, and kinesthetic strategies), 2 Repetitive (providing opportunities for practice and review), 3 - Structured (direct and explicit teaching of language patterns in a logical progression), 4 - Sequential (from simple to complex), 5 - Cummulative, 6 - Alphabetic/Phonetic (teaching sounds and letter-sound patterns from most frequent to least frequent), 7 - Metacognitive (helping students to think about language concepts and to explain them in their own words), Analytic/Synthetic (breaking multi-syllable words apart and putting them back together again). Apart from that, they also indicate that students with moderate or severe language learning difficulties may need additional accommodations like small groups, extra time, additional practice, reduced course load, or special classroom settings (e.g. space with minimal distractions). Brown and Ford (2007) also make some suggestions for including students with language learning difficulties in a foreign language classroom. They point out the importance of using shorter sentences and speaking slowly and clearly. Also, English language learners, and especially those with language difficulties, may not be able to understand English idioms, or may understand them literally, so teachers should be careful when using them. The authors suggest that, when asked a question, students with learning disabilities may need extra time to give an answer, and that it is necessary to 
provide a silent period for them to organize their thoughts without giving them hints or answering the question for them. Although some teachers are afraid that the above mentioned suggestions will make their class boring, as Brown and Ford (2007) point out "all English language learners, even those without learning disabilities, will benefit from strategies that focus on making language clearer and more comprehensible" (Brown \& Ford, 2007).

\section{CONCLUSION}

Many students experience problems and difficulties with foreign language learning, even those who have not previously shown any signs of possible learning disabilities. Sometimes learning disabilities are diagnosed in students after they have experienced difficulties in foreign language acquisition and achieved poor results. The literature reviewed in this paper has shown that regardless of the LD diagnosis, both students with learning disabilities and those with foreign language learning difficulties have problems in native language skills (typically phonological/orthographic aspects of language) and have weaker foreign language aptitude, which later have a negative influence on foreign language acquisition. Even though it is outdated, the MLAT still remains a significant predictor of foreign language proficiency. Apart from being well-educated, qualified, motivated, experienced, and proficient, foreign language teachers also need to be trained to work in an inclusive classroom. They should know how to recognize students with language learning disabilities or difficulties in their classroom and make appropriate instructional modifications to meet their needs. Different studies have shown that multisensory structured language (MSL) instruction has proved to be one of the best instructional methods for students with problems in foreign language learning. 
Specijalna edukacija i rehabilitacija (Beograd), Vol. 15, br. 4. 461-474, 2016.

\section{REFERENCES}

1. Brown, D., \& Ford, K. (2007). Communication Strategies for All Classrooms: Focusing on English Language Learners and Students with Learning Disabilities. Retrieved October 2016. from http:// www.ldonline.org/article/19260/

2. DiFino, S., \& Lombardino, L. (2004). Language Learning Disabilities: The Ultimate Foreign Language Challenge. Foreign Language Annals, 37(3), 390-400.

3. Ellis, R. (1994). The Study of Second Language Acquisition. Oxford: Oxford University Press.

4. Gajar, A. (1987). Foreign language learning disabilities: The identification of predictive and diagnostic variables. Journal of Learning Disabilities, 20(6), 327-330.

5. Ganschow, L. \& Schneider, E. (2006). Assisting Students with Foreign Language Learning Difficulties in School. Retrieved October 2016. from http://www.ldonline.org/article/22725/

6. Ganschow, L., \& Sparks, R. (2001). Learning difficulties and foreign language learning: A review of research and instruction. Language Teaching, 34(2), 79-98.

7. Ganschow, L., Sparks, R., \& Javorsky, J. (1998). Foreign Language Learning Difficulties: A Historical Perspective. Journal of Learning Disabilities, 31(3), 248-258.

8. Geva, E., \& Massey-Garrison, A. (2013). A Comparison of the Language Skills of ELLs and Monolinguals who are Poor Decoders, Poor Comprehenders or Normal Readers. Journal of Learning Disabilities, 46(5), 387-401.

9. Hallahan, D., Kauffman, J., \& Pullen, P. (2009). Exceptional Learners: An Introduction to Special Education. Boston: Pearson Education, Inc.

10. Harmer, J. (2001). The Practice of English Language Teaching. Harlow: Pearson Education Limited.

11. Ndlovu, K., \& Geva, E. (2008). Writing Abilities in First and Second Language Learners With and Without Reading Disabilities. In J. Kormos, \& E. Kontra (Eds.), Language Learners with Special 
Needs: An International Perspective (pp. 36-62). Clevedon, GBR: Channel View Publications.

12. Newhall, P. (2012). Language-Based Learning Disability: What to Know. Retrieved October 2016. from http://www.ldonline.org/ article/56113/

13. Ortiz, A. (2001). English Language Learners with Special Needs: Effective Instructional Strategies. Retrieved October 2016. from http://www.ldonline.org/article/5622/

14. Richards, J. (2001). Curriculum Development in Language Teaching. Cambridge: Cambridge University Press.

15. Sawyer, M., \& Ranta, L. (2001). Aptitude, individual differences, and instructional design. In P. Robinson (Ed.) Cognition and Second Language Instruction (pp. 319-353). Cambridge: Cambridge University Press.

16. Schwarz, R. (1997). Learning Disabilities and Foreign Language Learning. Retrieved October 2016. from http://www.ldonline.org/ article/6065

17. Skehan, P. (1991). Individual Differences in Second Language Learning. Studies in Second Language Acquisition, 13(2), 275-298.

18. Sparks, R., Patton, J., Ganschow, L., Humbach, N., \& Javorsky, J. (2006). Native Language Predictors of Foreign Language Proficiency and Foreign Language Aptitude. Annals of Dyslexia, 56(1), 129-160.

19. Sparks, R., Patton, J., Ganschow, L., \& Humbach, N. (2009). Long-term relationships among early first language skills, second language aptitude, second language affect, and later second language proficiency. Applied Psycholinguistics, 30(4), 725-755.

20. Spear-Swerling, L. (2006). Learning Disabilities in English Language Learners. Retrieved October 2016. from http://www. ldonline.org/spearswerling/Learning_Disabilities_in_English_ Language_Learners

21. Tonkyn, A. (1998). MAELT Second Language Learning Principles Materials. Reading: The University of Reading.

22. UNESCO. (2009). Policy Guidelines on Inclusion in Education. Paris: UNESCO. 
Specijalna edukacija i rehabilitacija (Beograd), Vol. 15, br. 4. 461-474, 2016.

\title{
NASTAVA STRANIH JEZIKA ZA UČENIKE SA TEŠKOĆAMA U NJIHOVOM USVAJANJU
}

\author{
Maja Ivančević Otanjac \\ Univerzitet u Beogradu - Fakultet za specijalnu edukaciju i rehabilitaciju
}

\begin{abstract}
Rezime
U radu je prikazan kratak pregled faktora značajnih za učenje stranih jezika, uz poseban osvrt na učenike koji ispoljavaju teškoće $\mathrm{u}$ njihovom usvajanju. $\mathrm{Na}$ osnovu dostupne literature, razmatran je uticaj veština maternjeg jezika i sklonosti ka stranim jezicima, na uspeh u usvajanju stranog jezika. Takođe, u radu se ističe značaj uloge nastavnika i nastavnih modifikacija i metoda odgovarajućih za učenike sa teškoćama u učenju stranih jezika.

Ključne reči: teškoće u učenju stranih jezika, veštine maternjeg jezika, sklonost ka učenju stranog jezika, nastavne modifikacije
\end{abstract}

Primljeno: 16.10 .2016$.

Prihvaćeno: 23.11.2016. 